\title{
Bank Regulation and Macroeconomic Fluctuations
}

\author{
Charles Goodhart, Boris Hofmann, \\ and Miguel Segoviano*
}

\begin{abstract}
Over the last two decades, macroeconomic cycles were frequently associated with boom-bust cycles in bank lending and asset prices, often followed by financial instability. In this paper we argue that (i) the new pattern of macroeconomic cycles is partly the result of banking-sector liberalization since the early/mid-1970s, which has increased the procyclicality of the financial system; (ii) the regulation of bank capital in the form of capital adequacy requirements is itself inherently procyclical and may therefore amplify business-cycle fluctuations; (iii) the new Basel II Accord may considerably accentuate the procyclicality of the regulatory system.
\end{abstract}

Keywords: Basel II, Asset prices, Bank lending. Procyclicality

JEL Classification: E30, E32, E44, E51, E63, G18, G28

* Professor. London School of Economics, Houghton Street, London WC2A 2AE, England U.K., (E-mail) CAEGOODHART@aol.com; Doctor, Deutsche Bundesbank Central Office, Economics Department, Wilhelm Epstein Str. 14. D-60431 Frankfurt am Main, Germany, (Tel) +49-69-9566-2518, (Fax) +49-69-9566-3082, (E-mail) boris.hofmann@bundesbank.de; Economist, International Monetary Fund, 700 19th Street, N.W. Washington, D.C. 20431, U.S.A., (Tel) +1-202-623-6260, (Fax) +1-202-589-6260, (E-mail) msegoviano@imf.org, respectively. This is a reprinted version by an agreement of the Oxford Review of Economic Policy (Oxford University Press). Paper prepared for the 13th Seoul Journal of Economics International Symposium held at Seoul National University, Seoul. 23 September 2005. Our thanks are due to the participants at the seminar at the Said Business School, Oxford, on July 1, 2004, and especially to C. J. Allsopp and C. Mayer, our main discussants.

[Seoul Journal of Economics 2006, Vol. 19, No. 1] 


\section{Introduction}

We start this paper, in the following section II-A, by recording the particular nature of business cycles in the decades immediately following World War II. 1945-71. During these years demand was kept high, and one means of limiting the inflationary consequences of that was by keeping the banking system under tight credit controls. So there were virtually no banking crises, and. consequently, bank regulation was light.

When liberalisation nonetheless occurred, partly under the influence of globalisation, the removal of exchange controls, information technology, etc., a general inflationary asset price boom-bust occurred in the early 1970s. After that, and particularly after Volcker's monetary policy shift in October 1979, the monetary authorities gradually learnt how to use a market-oriented monetary policy to maintain price stability. This stabilisation of general consumer prices was, however, accompanied by a reversion of the business cycle in some respects to the kind of pattern seen. for example. in the decades up till 1913 when again consumer prices remained stable. In this new pattern real shocks often tended to generate fluctuations in asset prices, which frequently led to asset price booms (bubbles) and busts, in which latter casc banks would often become fragile and fail.

In this context there was a need to strengthen financial regulation. not only nationally but also internationally, given the extent of global competition in financial intermediation. This is described in section II-B, where we particularly focus on the key role of the Basel Committee on Banking Supervision in enabling a co-ordinated international response to a global problem.

Nevertheless the Basel approach had several weaknesses. The first is that regulation is inherently pro-cyclical. Banks are weaker in recessions and when asset prices decline. The more that regulation is based on current assessed riskiness and current market valuations, the more procyclical the regulatory system will become. The second is that supervision is, almost necessarily, focussed on the Individual financial institution. But actions and procedures that may appear obvious and straightforward at the individual level may be damaging, especially if regulation reinforces herd activity, at the aggregate systemic level. So in our next section, section II-C. we consider not only the likely extent of procyclicality. but also steps that might be taken to miligatc it. 
Section II approaches this subject at a fairly high level of generality. So we have chosen to support this overview with three more focussed empirical exercises. The first of these, section III-A. shows how the relationship between liberalisation and a subsequent asset price boom-bust has been a common phenomenon, common to Western as well as Asian countries, in developed as well as developing countries.

In our main analysis, in section II, we suggest that an increase in required bank capital during downturns may exacerbate the recession. We seek to support that hypothesis, in section III-B, by looking (again) at the experience in the U.S.A. of the 'credit crunch' in the recession of 1990/91. when required bank capital adequacy ratios were being hoisted in the aftermath of the first Basel Accord in 1988.

Finally, in section III-C, we try to do a counter-factual simulation to see how banking capital adequacy requirements would have changed over recent history for a 'typical' bank in three countries. Mexico, Norway, and the United States, using three different regulatory approaches. These were:

(i) The Basel II standardised approach

(ii) The Basel II Foundation internal ratings based (IRB) approach

(iii) An improved credit risk method (ICRM)

What we show is that the introduction of the Basel II IRB approach may well considerably accentuate the procyclicality of the regulatory system.

\section{General Theoretical Analysis}

\section{A. The Changing Nature of Cycles and the Role of Asset Prices}

The characteristics of trade cycles, of crises. and of financial regulation have all been changing over time. Eichengreen and Bordo (2003) and Bordo et al. (2001) divide up the hundred and twenty years since 1880 into four main periods, 1880-1913, 1919-1939, 1945-1971 and 1973-1997. It is the third period that stands out as unique in several respects. First, inflation not only continued, but accelerated; this had never happened before then during peace-time. Second, in the developed world output and productivity growth was much higher than previously, or (with a few exceptions) subsequently, and unemployment low and stable. Third, there were no banking 
TABLE 1

CRISIS FrEgUENCY

\begin{tabular}{ccccr}
\hline \hline Year & $\begin{array}{c}\text { Banking } \\
\text { Crises }\end{array}$ & $\begin{array}{c}\text { Currency } \\
\text { Crises }\end{array}$ & $\begin{array}{c}\text { Twin } \\
\text { Crises }\end{array}$ & $\begin{array}{c}\text { All } \\
\text { Crises }\end{array}$ \\
\hline $1880-1913$ & 2.30 & 1.23 & 1.38 & 4.90 \\
$1919-1939$ & 4.84 & 4.30 & 4.03 & 13.17 \\
$1945-1971$ & 0.00 & 6.85 & 0.19 & 7.04 \\
$\begin{array}{c}1973-1997 \\
\text { (21 Countries) }\end{array}$ & 2.03 & 5.18 & 2.48 & 9.68 \\
$\begin{array}{c}1973-1997 \\
\text { (56 Countries) }\end{array}$ & 2.29 & 7.48 & 2.38 & 12.15 \\
\hline
\end{tabular}

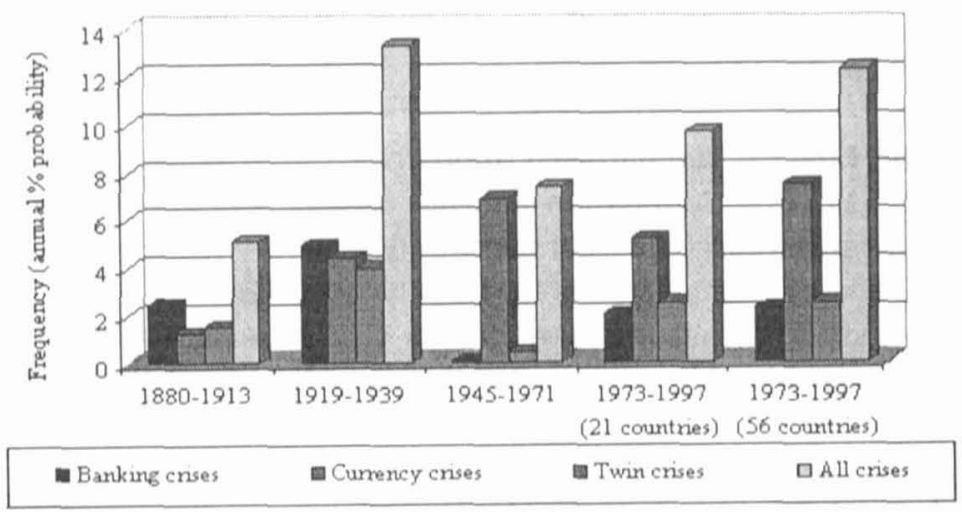

Figure 1

Crisis Frequency

crises, (see Eichengreen and Bordo. Table 3.5, reproduced here as Table 1; the same data are shown diagrammatically in Figure 1. taken from Bordo et al., Figure 1, p. 56), and, no doubt largely in consequence, bank supervision and regulation remained generally light. 1 In most countries, at least until the end of this period (1945-1971), bank lending to the private sector was not only directly

'For an account of the changing structure of bank regulation in the U.K., see Goodhart (2004). 
constrained by credit controls in aggregate, but also directed towards the preferred sectors of exporting and manufacturing companies.

Demand was generally kept high enough, primarily through expansionary fiscal policies. to keep unemployment below its 'natural' rate, so that inflation tended to accelerate from peak to peak. The monetary authorities would then raise interest rates to check inflation, and also the Balance of Payments/currency crises that attended the comparatively more inflationary countries. It was said that every boom in the U.S.A. during these decades was killed off by the Federal Reserve System. Thereafter, during the Stop intervals, of the Go/Stop cycles of the time, interest rates would be lowered out of a wish to hold down the cost of public sector indebtedness and to encourage private sector investment. The increases in interest rates, sharp though they sometimes were, caused relatively little financial fragility since the banks assets were primarily short-dated government securities and loans to large (and generally safe) private sector (manufacturing) companies.

The economically disastrous decade of the 1970s, with stagflation, brought about a reconstruction of the policy mix. In particular there was a maintained shift away from direct. central (government) controls towards market mechanisms. There was a similar shift from using fiscal policy, primarily to target a desired level of unemployment, to using monetary policy, primarily to target a (low and stable) level of inflation.

The banking system, owing to its central role in the economy, had been a focus for such prior controls, controls on interest rates, on credit allocation, on international financial flows (via exchange controls). So controlled were such commercial banks that they were seen as akin to public utilities, not commercial entities, boring, uninnovative, but safe. The main task of bank managers/loan officers was to say 'no' to requests for loans from prospective borrowers in less favoured sectors. Risk analysis and risk management atrophied in such circumstances.

It has, therefore. not been surprising that one facet of the liberalisation of banking systems around the world has been a subsequent lending boom and subsequent bust. As we document in section III-A this has occurred in country after country, starting perhaps in the U.K. where the liberalisation of 'Competition and Credit Control'. Bank of England, 1971 was shortly followed by the Fringe Bank Crisis in 1973/74 (see Reid (1982)). One common aggravating 
feature was that part of the business of the controlled commercial banks had, prior to the liberalisation. often been taken by new intermediaries whose raison d'etre was essentially to avoid such controls (with, or without, the blessing of the authorities). Once liberalised there was a grab for market share by the commercial banks to recover previously lost business and by the non-bank intermediaries to hold on to it. Stir in the lack of experience with risk management, and the shift of the largest. and safest borrowers to the capital markets, and the result was a danger of a boom-bust cycle. As noted in section III-A, this became the experience in Scandinavia in the early 1990s, Japan in the 1990s, much of East Asia in 1997/98; much the same syndrome may await India and China when they eventually liberalise. This experience, though general, was not, however, universal. Several major European countries, notably Germany, avoided any such experience. In the German case this may be attributed to their banking system being re-established, after World War II, on a relatively liberalised basis from the outset. Even so, the dangers of enhanced financial instability in the immediate aftermath of liberalisation indicate the need for ensuring that financial supervision and risk management skills are improved at the same time.

Liberalisation of banking systems has been one of the most potent progenitor of boom-bust cycles, but it has not been the only factor. Once the large companies, to whom the banks had primarily lent in the Eichengreen/Bordo third period (1945-71), had migrated to capital markets, banks increasingly began to lend to small and medium enterprises (SMEs) and to persons. Such smaller size borrowers were, in general. somewhat riskier, and the costs of acquiring information on a large number of idiosyncratic small borrowers were greater. So, banks placed increasing weight on collateral as a basis for lending. But this gave rise to the likelihood of enhanced dynamic instability, in the guise of the financial accelerator mechanism, see for example Bernanke. Gertler. and Gilchrist (1999) and Clarida. Gali, and Gertler (1999), or the cyclical mechanism of Kiyotaki and Moore (1997).

Essentially an upturn may be triggered by some good shock, e.g. to productivity or trade; profits incrcase, asset values rise; lending increases because collateral becomes more easlly available: enhanced lending raises investment, profits and asset values. This goes on until the rise in the capital stock becomes so large that profit margins 
crumble. Then. of course. everything goes into reverse. An interesting feature of such booms is that they are often characterised by stable real unit labour costs. (held down by productivity gains), stable prices (often held down by currency appreciation, partly owing to capital inflows), and seemingly prudent, or even robust, fiscal policies (with rising tax revenues and declining social expenditures); a markedly different profile from the earlier period.

Besides greater lending to SMEs, banks also increasingly muscled in to the business of mortgage lending to households, territory which had previously been confined to specialised (and often cartelized) mortgage lenders. Again a similar nexus between some favourable initial shock leading to higher housing prices, providing a stronger collateral basis for bank lending, with such lending tending to cause yet higher housing prices, and so on, could be discerned on numerous occasions in a variety of countries, though more so in Anglo-Saxon countries, where home ownership is prized, rather than in Continental Europe. especially where accommodation is more commonly rented.

Such characteristics have, of course, led to the debate on whether the monetary authorities could, and should, observe and then react to deviations of asset prices from some longer-term fundamental value, i.e. asset price bubbles: see in particular the debate between Cecchetti et al. (2000) and Bernanke and Gertler (1999); also see Gertler et al. (1998). This debate continues in the aftermath of the dot-com equity bubble and bust, but it is not the remit, or purpose, of this paper to discuss macro-monetary policies. Rather it is our objective to discuss how policies with respect to financial regulation and supervision inter-act with the cycle.

\section{B. Interaction between Regulation and the Trade Cycle}

These changing characteristics of the trade cycle, notably liberalised financial markets combined with sharp asset price fluctuations, have resulted in a crop of banking crises, and twin banking/currency crises. Looking again at Table 1 , the frequency of such crises reverted to the previous norm in 1880-1913, though still below that exhibited during the Great Depression in the inter-war years.

The liberalisation of financial markets was meant to, and did, enhance competition. Competition led to lower profit margins. A combination of factors led to the assumption of greater risk in 
loan-books, e.g. the migration of larger (and safer) borrowers to capital markets. initial (i.e. post-liberalisation) inexperience with risk management, the desire to break into new and unfamiliar markets, and a wish to maintain the return on equity (ROE) despite declining margins for safer business. Riskier business led to a rise in non-performing-loans (NPLs) and subsequent write-offs. Declining profit margins and higher NPLs, plus a desire to maintain ROEs, led to a trend decline in capital ratios. The decline in capital ratios implied worsening financial fragility.

As this was happening, in the 1970s, the institutions with particular responsibility for maintaining the systemic strength of the banking system were the Central Banks in the major developed countries. They had not. in practice, had much experience of such a role since the middle of the 1930s, but earlier historical developments had left them with that responsibility. As banking crises began to occur in the early 1970s, e.g. Franklin National (1973), Herstatt (1973/74), Fringe Bank Crisis (1973/74), many of the key Central Bankers became nervous.

Moreover. the growing development of international financial markets, the huge growth of international capital flows (following the removal of exchange controls), and the interpenetration of national financial markets at the wholesale level (and occasionally at the retail level also) by banks and investment houses with an international reach, meant that no single country, even the U.S.A., could maintain higher standards of financial probity unilaterally. The problem was that, absent exchange controls. financial intermediation could just move off-shore.

This led to onc of the more remarkable institutional developments of our age, the Basel Committee on Banking Supervision (BCBS). (initially called the Blunden and then the Cookc Committee, with these being the officials from the Bank of England who were its first two Chairmen). This Committee was established by the conclave of the Central Bank Governors of the G10 meeting under the auspices of the Bank for International Settlements. It had no formal or legal status, no governmental support (either international or national). Its pronouncements (Accords) were the softest of soft law. Yet there were sanctions to encourage adherence. The Central Banks of the countries with the main international financial markets were the leading members of the BCBS. If a country refused to abide by the Accords of the BCBS. the banks of that country could have their 
branches, and/or subsidiaries, banned from operating in the main financial centres.

As multi-national trade flourished and inter-national capital flows multiplied, so the leading banks and investment houses set up subsidiaries and branches in many countries. There was an urgent need to systematise and rationalise international procedures for banking supervision and, above all. to ensure that there was one lead regulator who could oversee the consolidated accounts of the bank as a whole, (a need evidenced for example by the Banco Ambrosiano collapse in 1981). The BCBS did much excellent work on this front. But their main concern was to halt and, indeed, to reverse the trend decline in capital ratios.

They achieved that objective with the introduction of the Accord on Capital Adequacy Requirements (CARs) in 1988. now generally known as Basel I. This was a great success for the BCBS, which by now really deserves a proper full-scale historical assessment (not attempted here). While Basel I was deservedly hailed as a great achievement, nevertheless it had a number of weaknesses. It is upon these that we shall now mainly focus.

First, the decision was made to try to relate banks' capital requirements to the relative riskiness of the assets. That is an understandable, some might say even an obvious, decision. But the measurement of risk is horribly complex. (finance academics spend a life-time on the subject). If the authorities try to lay down risk ratings, they run into a nasty dilemma. On the one hand, they can try to keep their risk measures simple and broad-brush, as in Basel I; but that will mean that such risk measurements will be inaccurate, and hence subject to gaming, arbitrage and avoidance, with unfortunate side-effects, as indeed happened with Basel $I$. On the other hand, they can try to make their risk-measurements as close to state-ofthe-art analysis as possible. Since risk measurement is complex, the resulting requirements will similarly become dense and difficult, the more so since analytical logic often has to compromise with national idiosyncrasies. Moreover the state-of-the-art is evolving over time - we would hope that it is improving - so that what may be correct today will become inaccurate tomorrow, and hence, perhaps, over time as subject to gaming, arbitrage and avoidance as simpler rules.

Moreover, the more detailed the rules, the more that it will tend to require those subject to them, i.e. the banks, to respond in exactly the same way to common shocks. That will enhance herd-like 
behaviour, one-way markets, that many observers already have seen as a danger. even before Basel II. In response to this. the BCBS can rightly state that the Internal Ratings Based (IRB) component of Basel II has been an instrument to induce the banks to improve their own individual modelling of (credit) risk. On this view Basel II is but a temporary phase (or step) in an evolving process whereby individual banks develop their own effective proprietary (credit) risk-metric models, preferably with continuing differences and innovation. Then, as has been happening with supervision of the trading/investment book, the supervisors could focus on oversight of bank models, and not to try to specify such models themselves. One continuing concern. however, is that the modelling needs of bankers differs from those of supervisors. Supervisors are mostly focussed on what would happen under extreme adverse events, in the far one-sided tails of probability distributions, whereas bankers need to be concerned about the full distribution of outcomes. Whereas Value at Risk (VaR) models do a good job most of the time. with their assumption of log normal distributions, and so are suitable for bankers, extreme events occur more often than in a normal distribution. (fat tails, kurtosis), and so the bankers' model was not, as it happened, of much use to supervisors.

The second weakness is that the supervision, the analysis, and the modelling, focusses primarily on the individual banking institution. not on the system as a wholc. These two weaknesses are inter-related in the sense that the realisation that supervisors could not rely on bankers own VaR models led to a new generation of stress tests, or scenario simulations, in which individual banks were asked to assess the effect on their own profitability, and capital adequacy, of the onset of certain extreme shocks. But there was no possibility whatsoever, in this attempt to estimate the cffect of a macro-shock on each individual micro institution, of examining dynamic interactions between banks (e.g. if bank A was forced to withdraw lunds from the interbank market, what effect would this have on bank $B$ ) or between bank reactions and the wider economy, (e.g. if banks would cut back on making new loans in the face of an adverse economic shock, would it Impart a serious further downwards impulse on the economy?). In short the macro/micro stress tests go only part-way to an assessment (and measurement) of systemic fragility.

Of course. the robustness of the system as a whole is related to the strength of the individual members. Given the myriad interconnec- 
tions between banks, if the individual banks are in poor condition, then the banking system as a whole is also likely to be fragile, and vice versa. Even so, it is perfectly possible to envisage circumstances where liquidity, or solvency, problems in one bank could have a cascade effect on other banks, perhaps via some combination of fund withdrawals and asset price declines. that could, possibly quite rapidly, bring initially healthy banks into serious difficulties. It is not possible to analyse and estimate such systemic weaknesses using present techniques.

Some steps have been taken to analyse the systemic implications of one of the most obvious sources of inter-connection, i.e. the interbank market. Here there have been various empirical studies (e.g. Elsinger et al. 2002; Furfine 2003; Upper and Worms 2004; Wells 2002), and the initial results have been quite reassuring. So long as pro rata payments on their inter-bank debts can be made quite quickly by failing banks, and/or concern about other banks' position with the failing bank does not trigger secondary (reputational) withdrawals of funds on them, then the first-round, direct effect of inter-bank linkages, via the interbank market, can almost always be comfortably absorbed.

This analysis underlines one of the problems about trying to analyse financial fragility. Developments in the financial system depend critically on the state of confidence. Given that we are dealing with the aftermath of assumed extreme shocks, which by definition occur very rarely, it is almost impossible to give any quantification about the potential likelihood of such secondary (reputational) effects, (though one might be able, at least in theory, to simulate them).

Be that as it may, with two colleagues at the Bank of England, one of us is trying to model the systemic effects of extreme shocks, e.g. Goodhart, Sunirand, and Tsomocos (2003). But that is somewhat separate from the main focus of this paper, and we will not pursue that further here.

A common problem in this field is that regulations that are entirely sensible when applied to the individual institution can have unwanted, and often unintended, macro, aggregate effects. This is particularly so when the individual institutions are all simultaneously affected by a common factor, notably the trade cycle as we will discuss in the following sub-section. But whenever a common factor affects a large proportion of the intermediaries at the same time, some unfortunate results may occur. 
A good example of this occurred in the case of the U.K. Life Insurance companies in 2002. In this case the downturn in the equity market, following the dot-com bubble and bust. put pressure on the LI companies' solvency ratios. whereby they have to demonstrate that they can meet their obligations to stake-holders even should (equity) markets continue to decline, (by another 25\%). The standard way to be sure of meeting such commitments is to match (hedge) the liabilities with assets of the same duration, and with a similar, fixed payment stream. So. the downturn in the equity market. interacting with the prudential requirements for solvency, forced the LI companies into selling equity onto a falling market, whilst buying long-dated (government) bonds on a rising market, thereby exacerbating both market trends. Moreover, their predicament was obvious to others, who could attempt to benefit by front-running speculation.

\section{The Procyclicality of Regulation}

The main common factor to affect banks, and most other financial intermediaries, is the trade cycle, i.e. generalised fluctuations in the economy. Regulation is inherently procyclical. Borrower and bank profits rise during booms; new capital is easier to raise; asset prices are higher. Per contra, in a downturn non-performing loans, failures and write-offs increase. Prudential regulations bite harder during periods of economic weakness because the individual banks are, indeed, more fragile. So, the more accurately the value, and relative riskiness, of each bank is measured at any point of time, the greater will be the procycilcality of the prudential regime. Thus Basel II will be more procyclical than Basel I: fair value accounting methods more than historic cost; point-in-time ratings more than those averaged through the cycle; and advanced internal risk based assessments more than foundation IRB, especially so since Loss Given Default (LGD) is to be treated as constant over time in the foundation method, whereas almost all empirical studies have found LGD to be strongly cyclical, perhaps as much, or more so, than the probability of default (PD), e.g. Acharya et al. (2003). Altman (2002). Altman et al. (2002).

This proposition. that the greater the accuracy of current valuation, the greater the resulting procyclicality of prudential regulation, is generally accepted. A much more problematic question is what the practical, emplrical scale of this relationship may be, and how 
important the resulting macro-economic consequentials may have been. We examine these issues in two studies in the empirical section of this paper. In section III-B we reconsider whether, and how far, the requirement for additional capital. in order to satisfy the newly imposed CAR of Basel I, exacerbated the recession of 1991/92, especially in the U.S.A. where most of the empirical studies were carried out. The problem. as usual in such exercises, is to identify, and hence to separate. the relative effects of demand and supply on the flow of new bank loans.

The second exercise. which we undertake in section III-C, is to simulate the comparative effect of Basel II, relative to Basel $I$, on CARs over the course of the cycle. For this purpose we use a data set from Mexico that was available to one of the authors (M. Segoviano). We also use data sets from Norway and the U.S.A., and comment on some other empirical exercises in the literature.

This procyclicality of prudential regulation tends to exacerbate the trade cycle itself. We have already mentioned the example of the solvency regulations on Life Insurance companies enhancing the boom-bust experience on the London Stock Exchange. By the same token if banks, in aggregate, are subject to binding prudential constraints on their lending in downturns, (which constraints are relaxed during booms), the amplitude of the cycle is likely 2 to be greater.

Of course, if the scale of this problem of procyclicality is small, then we need not worry so much. But the empirical exercises in section III-C, though as always inconclusive, suggest that the scale could be large. That raises the question of how best to respond.

One approach is to use some kind of averaging of the data over the cycle, to use historic cost accounting, or constant PDs (as in Basel $n$ ), or constant LGDs (as in the Foundation approach), or through-thecycle ratings. But this goes against the grain of trying to obtain the best, and most accurate, valuations in order to guide efficient market pricing, investor information and capital allocation.

A second possible response is to try to use fiscal, rather than

${ }^{2}$ A counter-argument is that, should the binding prudential regulations during downturns succeed in reducing the number and scale of bank failures, then the probability of systemic collapses during the recession will have been lessened. Likewise the greater sophistication of risk measurement methods may encourage private sector bank managers to curb their own risks in a voluntary manner. 
monetary. measures to mitigate such pro-cyclicality. Capital gains taxes may limit the volatility of post-tax returns. In so far as various taxes can be adjusted according to the condition of asset markets, they could be used by the authorities to mitigate pro-cyclicality. But this depends not only on the authorities having somehow better information on 'fundamental' asset prices, but may also introduce other distortions which usually have adverse effects.

A third, and perhaps more promising, approach is to adjust the prudential parameters. (to be applied to the most accurately estimated valuations), contra-cyclically over the cycle (Gordy and Howells 2004). This possibility, however, depends, quite largely, on their being an identifiable cycle, which can be expected to revert back to some (estimated) normal. mean level.

Assume, for example, that there is a recognised tendency for there to be mean-reversion towards some (calculable) Price/Earnings ratio in the equity market. Then the solvency ratio calculations that are prescribed should require that the percentage fall that the LI should be able to withstand should be an increasing function of the current level of the $P / E$ in the equity market. Similarly loan to valuation ratios in mortgage and property markets should, in principle, be functions of the deviation of housing/property prices from their equilibrium level.

An obvious problem in this respect. both for the economy as a whole and for the key asset markets, is that mean-reversion is an extremely weak and unreliable force. (think of foreign exchange markets) and that the ability to observe a long-run fundamental equilibrium is equivalently weak and doubtful. There is always a possibility that "there really is a New Economy." Although this latter is most often a (and in some cases a self-seeking) delusion, trends, e.g. in productivity, do change. Estimates of output gaps, and of equilibrium asset prices, will always be extremely unreliable. Nevertheless there is a case that it would be better to tie prudential parameters to such unreliable estimates than to hold them constant over the cycle. which must have adverse effects on procyclicality. Thus it would be possible to require some contra-cyclical variation in minimum CARs, raising these during booms and allowing these to fall back again during recessions.

Many might welcome this idea in principle, but argue that, since the estimate of the deviation from the norm is inevitably somewhat subjective. this should properly come under Pillar 2 of Basel II, as an 
optional, discretionary add-on for national supervisors, rather than as part of any agreed rule-book. And some supervisors may already be attempting to follow this course. There is some force in this argument, but it runs up against the problem that different national authorities will respond in different ways, so that international banks will vocally complain if their national authorities impose unilaterally higher CARs on them during expansions. Note also that minimum CARs will be required by formal regulation, e.g. EU directives, under Pillar 1, so that national supervision will not, (at least not officially), be allowed to combine higher ratios during expansions with ratios below the Pillar 1 requirement in recessions. So a draw-back of $\mathrm{Basel}$ $I I$ is that any national supervisor trying to build in some contracyclical effects into their own approach will simultaneously expose their own banks to higher over-time average CARs. There will be a clash between the desire for greater stability and the desire to allow their own banks to maintain international competitiveness.

Nevertheless the main problem with this approach lies in the weakness of mean reversion and the difficulty of observing deviations from fundamentals. Once events have safely become past history, enabling the commentator to draw trend lines, historical cycles come to appear immediately obvious. If one, however, allows for changing trends, and other breaks in the time series, (and these have happened before now), then the estimates of current deviations (from "fundamental" norms) become a matter of hot, and difficult, argument. Perhaps the strongest argument for Alan Greenspan not raising interest rates to constrain the dot-com bubble was that this would have been extremely difficult to justify to the U.S.A. Congress and the American people, the more so since there were many siren voices, and gullible investors, (see Brennan (2004)), who did not see the run-up in equity values as an unsustainable bubble. If it is too difficult for those in charge of monetary policy to assess deviations from fundamental equilibrium, ${ }^{3}$ why should financial regulators and supervisors be better endowed with economic insight?

\footnotetext{
${ }^{3} \mathrm{~A}$ counter-argument is that monetary policy makers already aim to assess deviations from long-run equilibrium in the guise of the output gap. so should they not be willing to assess similar deviations from equilibrium elsewhere in the economy, e.g. in the housing market. Against this it can be replied that the aggregate economy is generally more stable, and more predictable, than individual asset markets such as housing, or equities, or foreign exchange.
} 
A somewhat simpler alternative. to relating regulatory parameters to deviations from the norm. is to relate them to rates of change, relative to past average rates of change. These latter are eastly calculated, (though the length of the window over which the average is to be calculated is both somewhat arbitrary and can, at times, be substantively important). The rate of growth of bank lending to the private sector has, in the past. been a good predictor of financial crises, t.e. it is unusually high before crises. Again bubbles in asset prices tend to be characterised by accelerating prices as the peak, and resulting crisis/collapse is reached. If solvency requirements, loan to value requirements, etc.. were related to prior rates of change. it should help to avoid pro-cyclicality.

All this discussion, however, is reminiscent of the long-past discussion on ways to stabilise the macro trade cycle via derivative or integral stabilisation, etc. Much of that, however. got washed away in the general attack on fine-tuning. and the belief that demand management is better focussed on long-term rules. such as achieving an inflation target and sticking to a set of "golden" fiscal rules.

By the same token one can ask whether it is the purpose of regulatory policy to concern itself with the amplitude of cyclical swings? Perhaps not, but then it is surely the purpose of regulatory policy to avoid systemic crises, rather than to prevent all individual fallures. At present. the focus of financial regulation and supervision is on the individual institution. not on the system as a whole. Through the indirect effects of procyclicality, it is at least possible that the current, and prospective, methods of individual institutional supervision could have damaging implications for the system as a whole.

\section{Empirical Analysis}

\section{A. Financial Liberalisation. Credit Cycles, and the Changing Role of Asset Prices}

Since the mid 1970s there have been extensive efforts to liberalise banking systems in both developed and developing economies. ${ }^{4}$ The

\footnotetext{
${ }^{4}$ For a chronology of financial liberalisation in developed and developing markets see Kaminsky and Schmukler (2002).
} 
trend towards financial liberalisation was motivated by theoretical and empirical findings that higher financial development leads to higher economic growth and that financial liberalisation was, in turn, a precondition for financial development. Theoretically, by easing financial constraints and improving the efficiency of the banking system, banking sector liberalisation stirs higher and more efficient investment in both physical and human capital and thus spurs faster long-run growth. ${ }^{5}$ Empirically, this hypothesis appears to be supported by the data (see e.g. Leahy et al. (2001)).

In recent years, however, the perception of financial liberalisation has become more critical, owing to the recurrence of violent boom-bust cycles in credit creation, economic activity and asset markets in the wake of financial liberalisation. These boom-bust cycles often ended in outright systemic crisis of the banking sector. A central finding of the large and growing literature on the causes of banking crises is that financial liberalisation significantly increases the probability of a banking crisis. Various studies (Demirgüc-Kunt and Detragiache 1998: Kaminsky and Reinhart 1999) have shown that indicators of financial liberalisation help to explain the occurrence of banking crises in large samples of developing and developed countries.

Rather surprisingly, only few studies have tried to derive stylised facts for the development of key macroeconomic and financial variables in the wake of financial liberalisation. ${ }^{6}$ Anecdotal evidence, e.g. Drees and Pazarbasioglu (1998) for the Nordic countries and Collyns and Senhadji (2002) for the East Asian countries, suggests that financial liberalisation is followed by boom-bust cycles in bank lending, economic activity and asset prices, especially real estate. In order to asses whether this finding also holds on a broader basis of

\footnotetext{
${ }^{5}$ See Levine (1997) for a survey of the relationship between financial development and growth.

${ }^{6}$ Reinhart and Tokatlidis (2001) derive stylised facts for the long-run effects of liberalisation for a large sample of developed and developing countries. They analyse the development of key macroeconomic variables, national account aggregates. monetary and credit aggregates and interest rates before and after dates of financial liberalisation in order to assess whether the pre and post-liberalisation mean of each indicator is significantly different. Kaminsky and Schmukler (2003) focus on the effects of financial liberalisation on the volatility of stock prices. They find that liberalisation leads to more pronounced boom-bust cycles in the short-run, but more stable stock markets in the long-run.
} 
financial liberalisation episodes we looked at the development of real GDP, bank lending, property prices and share prices in the wake of financial liberalisation for a sample of 16 OECD countries, Australia, Belgium, Denmark, Finland. France, Ireland, Italy, Japan, Korea, New Zealand. Norway, Spain, Sweden. Switzerland. the U.K., and the U.S.A.7

Figure 2 shows the unweighted country average (solid line) of the development of real GDP growth, the change in real bank lending, the change in real property prices and the change in real share prices (four-quarter growth rates) in the ten years following financial liberalisation together with upper and lower quartiles (dotted lines). The figures reveal that, on average. financial liberalisation is followed by a boom-bust cycle in economic activity, bank lending and asset prices. Real GDP growth starts to rise immediately after liberalisation and peaks after about three years. Then real growth gradually declines and falls below its initial value after about five years. Real lending growth starts to rise about five quarters after the date of liberalisation and peaks after about three years. Subsequently, the growth rate of real lending declines and falls below its initial value after about seven years. Property prices start to rise one year following liberalisation. The increase in property prices peaks after about three years and then gradually declines. After about six years, property prices start to fall. Real share prices appear to be rising at a brisk pace already at the time of liberalisation. After liberalisation, the increase in share prices further accelerates and peaks after about six quarters. About five years after liberalisation, share prices are falling. Thus, the sample averages appear to support the notion that episodes of financial liberalisation are followed by pronounced boom-bust

\footnotetext{
${ }^{7}$ Financial liberalisation dates were identifled based on information provided in Abiad and Mody (2003), Kaminsky and Schmukler (2003). Glick and Hutchison (1999), and Drees and Pazarbasioglu (1998). The dates of liberalisation for the individual countries are 1985 for Australla, 1986 for Belglum, 1981 for Denmark, 1986 for Finland, 1985 for France, 1981 for Italy, 1985 for Japan. 1988 for Korea. 1985 for New Zealand, 1983 for Norway, 1981 for Spain. 1983 for Sweden. 1989 for Switzerland. 1981 for the U.K., and 1982 for the U.S.A. Note that the date taken for the U.K. from this literature differs from that specified earlier in section II-A, which was 1971. This Indicates both that liberalisation can proceed through several waves, (so there may be several valid dates for a single country). and that such dating inevitably involves some, potentially fallible. subjective judgement.
} 


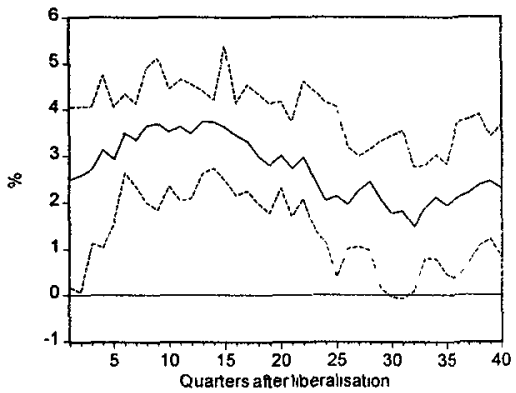

Real GDP growth

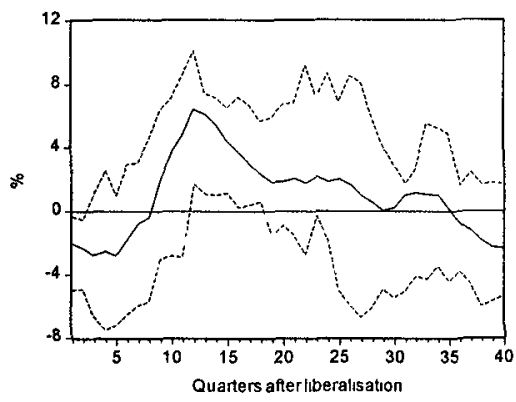

Change in real property prices

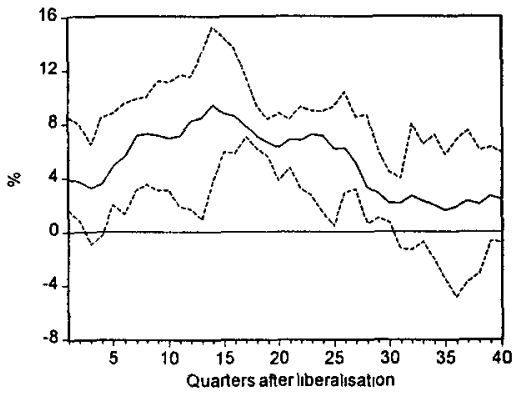

Change in real bank lending

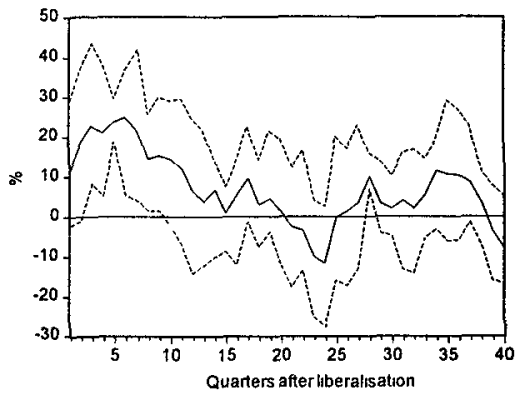

Change in real share price

Note: Solid lines are sample averages, dotted lines are upper and lower quartiles.

\section{Figure 2}

Post-Liberalisation Cycles

cycles.

The upper and lower quartiles, which are also displayed in Figure 2 , also reveal, however, that there is substantial variation in the movements of the variables across countries. A look at the individual country level data, which we do not discuss here for the sake of brevity, ${ }^{8}$ suggests that all countries experienced a cycle after financial liberalisation, but that there substantial variation in the timing of the

${ }^{8}$ Individual country level data are available from the authors upon request. 
occurrence of the cycle. This, may, however, partly be due to unavoidable imprecision in the exact dating of liberalisation episodes.

Why do boom-bust cycles evolve in the wake of financial liberalisation? Financial liberalisation relaxes the borrowing constraints faced by the private sector and therefore has similar effects to a positive. permanent productivity shock to the economy. In models with credit constrained borrowers, ${ }^{9}$ a positive productivity shock gives rise to a boom-bust cycle in lending, economic activity and asset prices. A positive productivity shock leads to an increase in the value of collateralisable assets. As the borrowing capacity of entrepreneurs depends on the value of their collateralisable assets. this gives rise to higher lending, which in turn further fuels economic activity and asset prices, which again increases borrowing capacity, and so on. Eventually, all variables converge back to their steady state levels and the boom turns into a bust. The result is a credit cycle a la Kiyotaki and Moore (1997). Thus. from the perspective of models with credit constraints, the evolution of a boom-bust cycle in the wake of financial liberalisation is fully consistent with theoretical models with credit constraints and a financial accelerator.

Financial liberalisation is in fact even likely to be associated with a strengthening of the financial accelerator mechanism and thus to give rise to more pronounced boom-bust cycles. As the liberalisation of banking systems has usually been accompanied by liberalisations of capital and stock markets, it became easier for the largest and safest borrowers of banks to raise funds on the capital and stock market. 10 As a consequence, banks tried to make good the lost business by be beginning to lend to small and medium enterprises and persons. These smaller borrowers were, in general. somewhat riskier and the costs of monitoring these small borrowers were higher, so that banks placed increasing weight on collatcral as a basis for lending. As a result, changes in the value of collateralisable assets, predominantly property, are likely to have a stronger impact on lending after liberalisation.

In order to test this hypothesis empirically. we performed rolling regressions for a reduced form credit growth equation. where we

\footnotetext{
${ }^{0}$ The basic references of this literature are Bernanke and Gertler (1989) and Kiyotaki and Moore (1997).

${ }^{10}$ See Kaminsky and Schmukder (2003) for a cross-country chronology of banking sector and stock market liberalisations.
} 
regressed the change in real bank lending $(\Delta c)$ on its own lag, the lagged change in real property prices $(\Delta p)$, the lagged change in real GDP $(\Delta y)$ and the lagged change in the ex-post short-term real interest rate $(\Delta r)$ :

$$
\Delta c_{t}=\beta_{1} \Delta c_{t-1}+\beta_{2} \Delta p_{t-1}+\beta_{3} \Delta y_{t-1}+\beta_{4} \Delta r_{t-1}+\varepsilon_{t}
$$

Equation (1) was estimated by OLS for a sample of OECD countries over a rolling window of 15 years with quarterly data. In order to have a first coefficient estimate for a sample period covering mainly the pre-liberalisation period, availability of all explanatory variables back to the early 1970s was required. This data requirement reduced the sample of countries for this exercise to ten: Australia. France, Italy. Japan, New Zealand, Norway, Sweden. Switzerland, the U.K., and the U.S.A. The estimated rolling property price coefficients are displayed in Figure 3 in a 5\% confidence band. The graphs appear to support the hypothesis of an increasing effect of property prices on bank lending. Except for Australia and New Zealand, there is for all countries a clear and significant increase in the rolling property price coefficient over the 1990s. A comparison of the first and the last rolling coefficient estimate makes a clear case. The first property price coefficient estimate of the rolling regression, which corresponds to the sample period covering the pre-liberalisation period from the early 1970 s to the mid $1980 \mathrm{~s}$, is insignificant in all countries. In stark contrast, the last property price coefficient estimate of the rolling regression, which corresponds to the sample period first quarter 1987 to fourth quarter 2001, where domestic banking sectors in all countries under investigation were fully liberalised, is significant at least at the five percent level in seven out of ten countries. The rolling regression results therefore clearly support the view that bank lending has become more sensitive to property price movements in the wake of financial liberalisation.

\section{B. Macroeconomic Effects of the Basel Accord}

One of the responses to the increase in bank and thrift failures in the 1980s, especially in the U.S.A., and excessive risk taking by commercial banks in the wake of financial liberalisation, was the introduction of the Basel Capital Accord in 1988. ${ }^{11}$ The Basel Accord requires international banks to “... hold capital equal to at least 


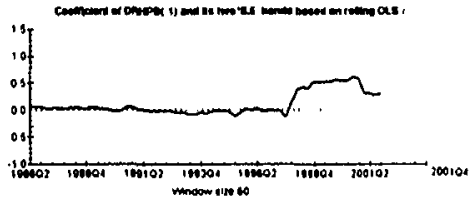

U.S.A.

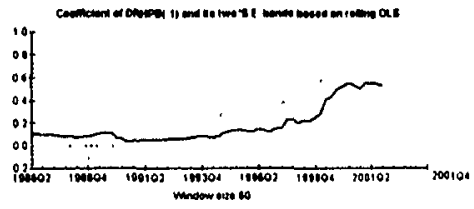

France

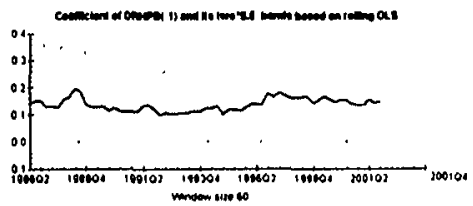

U.K.

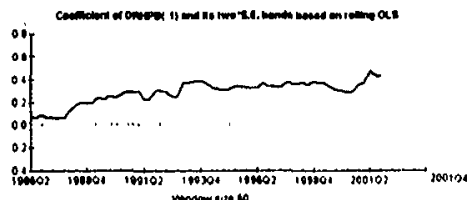

Sweden

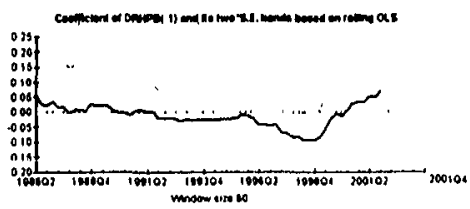

Australla

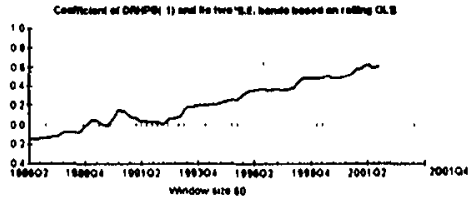

Japan

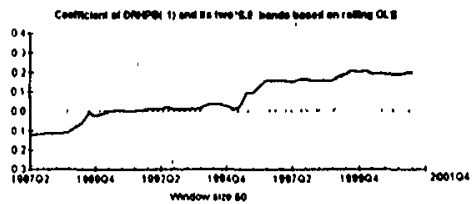

Italy

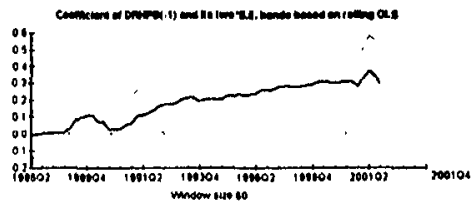

Swltzerland

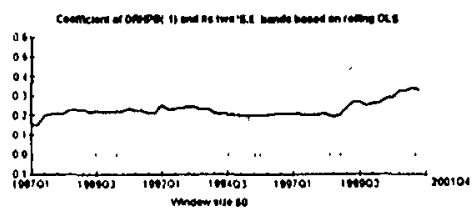

Norway

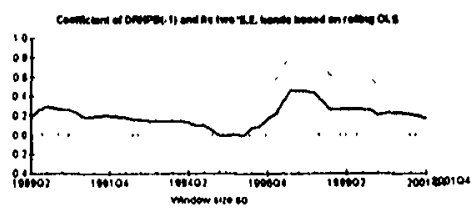

New Zealand

Note: The graphs report rolling OLS estimates of the property price coefficient in Equation (1) over a window of 15 years.

Figure 3

The Increasing Sensitivity of Bank Lending to Property PRices 
$8 \%$ of a basket of assets measured in different ways according to their riskiness." (see Basel Committee on Banking Supervision, 1988). For example, low risk assets, like Treasury securities, have a 0 percent risk-weighted capital requirement, while high risk assets, like claims on commercial companies have a 100 percent risk weight. As a result, regulatory capital adequacy became more risk sensitive and the disincentives to hold liquid, low risk assets were reduced. 12

Basel Committee on Banking Supervision (1999) show that the introduction of the Basel Accord was followed by an significant increase in average risk weighted capital ratios in the G10 countries. Risk weighted capital ratios can increase by increasing regulatory capital (the numerator) or by reducing risk-weighted assets (the denominator). Figure 4 shows the development of regulatory capital, risk weighted assets and the CAR in the U.S.A. since 1990.13 The graphs reveal that the marked increase of CAR from $9.5 \%$ to above $13 \%$ between 1990 and 1993 was brought about by both an increase in regulatory capital and a decrease in risk weighted assets. This, implies that the increase of CAR may have caused a reduction in the supply of credit to the economy, which is in the literature referred to as a 'credit crunch'. It is often argued that the adverse credit supply effects of the Basel Accord may have exacerbated the 1990/91 recession. A convincing proof of this hypothesis is still missing, mainly due to the problem with identifying and separating credit demand and credit supply movements.

Movements in real activity influence credit demand and movements in credit supply may influence real activity, which gives rise to a simultaneity problem, which has not yet been resolved convincingly. Figure 5 shows the development of real GDP growth and nominal lending growth in the U.S.A. since 1965. The graph reveals that economic activity and credit creation are closely correlated over the

\footnotetext{
${ }^{11}$ Secretariat of the Basel Committee on Banking Supervision (2001) states on p. 11 "the major impetus for the 1988 Basel Capital Accord was the concern of the Governors of the G10 central banks that the capital of the world's major banks had become dangerously low after persistent erosion through competition."

${ }^{12}$ See Basel Committee on Banking Supervision (1999).

${ }^{13}$ The data were taken from the BIS database. Unfortunately, there was no longer time series available for the U.S.A. For other countries, time series data for risk adjusted capital ratios and risk weighted assets, if at all available, do not go back further than the late 1990s.
} 


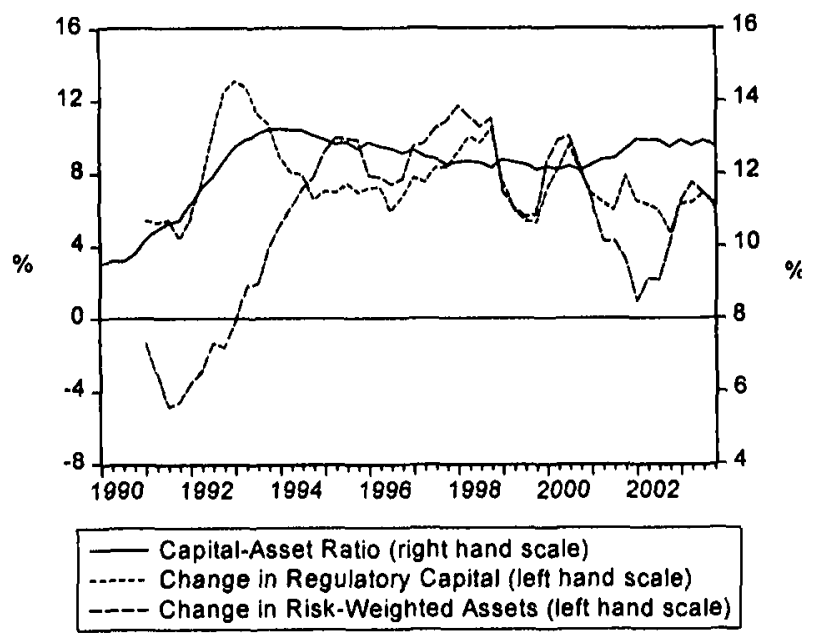

Source: FDIC

Figure 4

The Capital-Asset Ratio and Its Components FOR U.S.A. COMMERCLAL BANKS

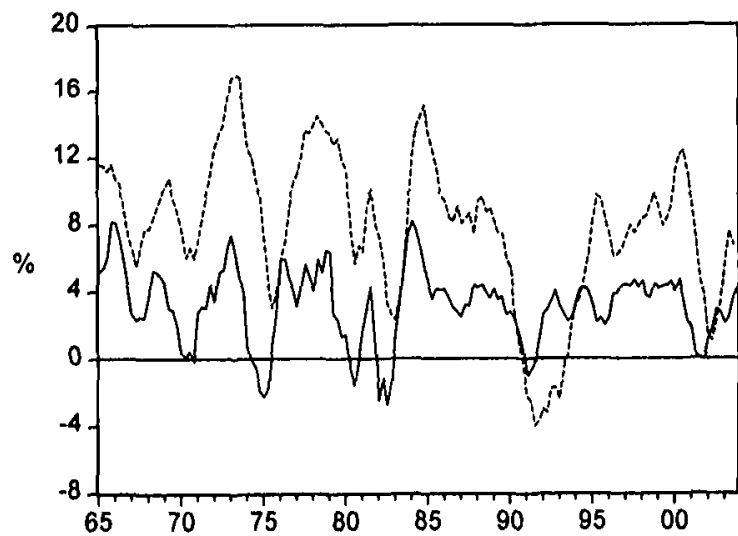

- Real GDP Growth Change in Nominal Bank Lending

Figure 6

EConomic ACtivity and CRedit CREation IN the U.S.A 
cycles, which may be reasonably explained by the effect of economic activity on credit demand. The three recessions of 1974/75, 1980/82 and 1990/9l were all accompanied by slowdowns in credit creation. However, the 1990/91 recession was the only case where credit growth turned negative. The downturn in bank lending was therefore stronger than would have been expected from prior experience. This is often taken as evidence that additional adverse supply effects were at work at that time.

Various empirical studies have investigated this question by looking at the significance of credit supply determinants in credit growth regressions (see e.g. Berger and Udell (1994)). An alternative strategy, followed e.g. by Walsh and Wilcox(1995), is to take independent movements in the prime lending as an indication of changes of credit supply conditions. The prime lending rate (which was never a market determined rate) used to be considered the rate at which banks lend to their best corporate customers. In practice, however, the best corporate customers borrow at rates below prime and the prime lending rate is more a benchmark rate used to price loans for smaller firms and for less credit worthy large firms. In the long-run, lending rates are set as mark-up over the bank's marginal cost of funds, which is in the case of the prime rate given by the federal funds rate. The mark-up of lending rates over the bank's marginal cost of funds is a function of the additional costs a bank incurs when extending a loan, such as the cost of doing a credit evaluation and, in particular, the cost of raising the capital to meet the capital requirement for the loan. This implies that, given that capital requirements have been tightened by the Basel Accord, the spread of the prime rate over the federal funds rate would be expected to rise. which would be an indication of an adverse supply effect on the credit market. Figure 6 shows the development of the prime lending rate and the federal funds rate since 1980 . The graph suggests that the spread of the prime rate over the federal funds rate has in fact widened around $1990 / 91$.

The hypothesis of a significantly widening spread of the prime rate over the federal funds rate can be tested more formally based on unit root tests. In an influential paper. Perron (1989) has shown that the presence of one time breaks in the trend or mean of a time series gives rise to non-rejection of the unit-root hypothesis in a standard unit-root test, such as the standard augmented Dickey-Fuller (ADF) test (Dickey and Fuller 1981). Perron has proposed a consistent 


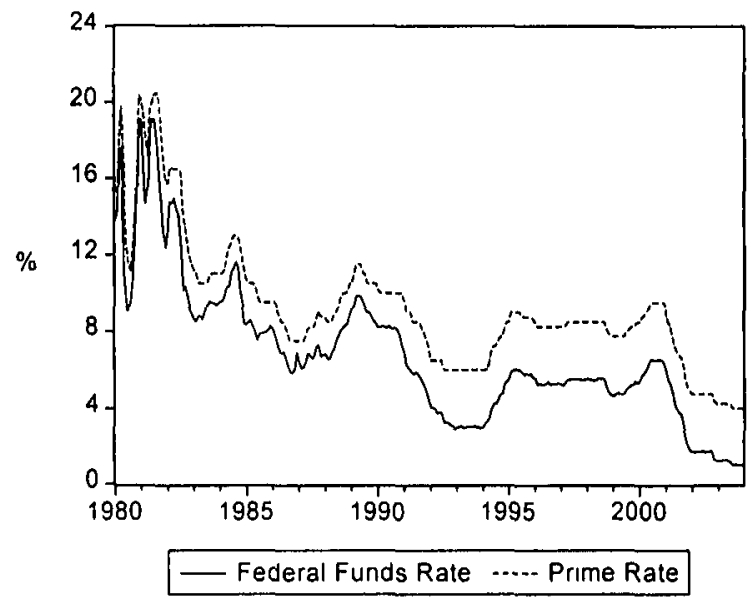

Figure 6

The U.S.A. Prime Lending Rate and the Federal Funds Rate

testing strategy against breaking trend and means, both for the case of known breakpoints (Perron 1989, 1990) and for the more general case of unknown breakpoints, where the dates of shifts in the mean or the trend are endogenously determined in the testing procedure (Perron 1997).

We start by testing the time series property of the spread of the prime rate over the federal funds rate based on standard ADF test over the period 1980-2003 based on monthly data taken from the IMF International Financial Statistics. The test is based on the following regression:

$$
\Delta x_{1}=\alpha+\delta t+\gamma x_{1} \quad++\sum_{i=1}^{n} \beta_{i} \Delta x_{t-1}+\varepsilon_{1}
$$

where $x$ is the spread and $t$ is deterministic time trend. The test of the null hypothesis of a unit-root is based on the $t$-statistic of the coefficient $\gamma$. If $\gamma$ is significantly different from zero, the null of a unit-root can be rejected. Since the distribution of the test statistic is non-standard under the null, the standard critical values do not apply. The $5 \%$ critical value tabulated in Mackinnon (1991) is -2.87 for the test regression with a constant but without a deterministic 
TABLE 2

Unit RoOT TESTS FOR THE SPREAD OF THE PRIME RATE OVER THE FEDERAL Funds Rate

\begin{tabular}{ccc}
\hline $\begin{array}{c}\text { ADF Test } \\
\text { (constant and trend) }\end{array}$ & $\begin{array}{c}\text { ADF Test } \\
\text { (constant and no trend) }\end{array}$ & $\begin{array}{c}\text { Perron Test } \\
\text { (innovational outlier } \\
\text { model) }\end{array}$ \\
\hline-2.65 & -1.99 & -5.03 \\
\hline
\end{tabular}

Note: The $5 \%$ critical values are -3.43 for the $\mathrm{ADF}$ test with a constant and a trend, -2.87 for the $\mathrm{ADF}$ test with a constant but without trend and -4.80 for the Perron test for the innovational outlier model.

time trend and -3.43 for the case with a constant and deterministic time trend in the test regression. The ADF test statistic for both cases is reported in Table 2. The lag order of the lagged dynamic terms was chosen based on sequential lag reduction tests starting with a maximum lag order of twelve, which suggested retaining the maximum number of twelve lags. In both cases the null of a unit root cannot be rejected. This finding would imply that there is no long-run relationship between the prime rate and the federal funds rate. An alternative interpretation, which would be suggested by Figure 6 , is that there was a shift in the mean of the spread around the time of the introduction of the Basel Accord and that the non-rejection of the unit root hypothesis merely reflects the failure to take this shift into account in the testing procedure.

In order to assess which interpretation is right, we apply Perron's (1997) unit root test with a break in the mean at an unknown date. The test is based on the test regression:

$$
x_{t}=\alpha+\delta t+\gamma x_{i-1}+\lambda D U_{t}+\theta D\left(T_{b}\right)_{t}+\sum_{i=1}^{n} \beta_{i} \Delta x_{t-1}+\varepsilon_{t},
$$

where $D U_{t}=1\left(t>T_{b}\right)$ and $D\left(T_{b}\right)_{t}=1\left(t=T_{b}+1\right)$. Perron (1997) terms this model, where only a break in the mean is allowed for, the 'innovational outlier model'. ${ }^{14}$ The unit root test is performed based on the $t$-statistic for the null hypothesis $\gamma=1$. The lag order of the lagged dynamic terms was again chosen based on sequential lag reduction tests starting with a maximum lag order of twelve, which

\footnotetext{
${ }^{14}$ In the second model he proposes, the 'additive outlier model', both the mean and the trend are allowed to break.
} 
suggested retaining ten lags. The break date was endogenously determined by calculating the unit root test statistic for all possible break dates and then choosing the date that minimises the unit root test statistic. The break date chosen by the testing algorithm is September 1990 and the final test regression is given by:

$$
x_{t}=\underset{(5.18)}{0.529}-\underset{(-1.26)}{0.0004} 4 t+\underset{(14.29)}{0.739 x_{1-1}}+\underset{(4.28)}{0.345 D U_{t}}+\underset{(-0.95)}{0.251} D\left(T_{b}\right)_{l}+\sum_{i=1}^{10} \beta_{t} \Delta x_{t-1}+\varepsilon_{t}
$$

with $D U_{t}=1(t>1990: 9)$ and $D\left(T_{b}\right)_{t}=1(t=1990: 10)$. The regression results suggest that the mean spread is significantly higher after September 1990. The unit root test statistic, which is reported in Table 2 , is given by -5.03 which compares with a $5 \%$ critical value of -4.80 . Thus, the Perron unit root test with unknown breakpoint suggests that the spread of the prime rate over the federal funds rate is stationary around a constant mean which breaks in September 1990 and that the mean spread appears to be higher after the break. These results give some indication of potentially lasting supply effects of the introduction of the Basel Accord on the U.S.A. credit market.

\section{Basel and Procyclicality}

Our procedure here is to try to reconstruct a typical bank portfolio for a country and then, holding the presumed loan book unchanged over ume, (i.e. replacing falled loans with loans of a similar quality). to examine how the loan ratings would have shifted, and hence how the capital adequacy requirements for the banks would have varied over time; for other similar exercises see Kashyap and Stein (2004) and Gordy and Howells (2004). To do this we use Moody's data on U.S.A. corporate bonds, included on Moody's Investors Service, Credit Risk Calculator. We can only do this exercise for those countries for which Moody's data on credit ratings has a long enough time series. Unfortunately this rules out most large European countries since adequate Moody's data only goes back to 1988 for the U.K.. 2001 for Germany; 2002 for France; 2003 for Italy; 2002 for Spain. In the event we used data provided by the Mexican Financial Regulatory Agency and the Norwegian Central Bank on Corporate Loans. The Mexican data incorporates information between 1995 and 2000 and the Norwegian data incorporates information between 1988 and 2001 .

This sounds easier than it actually is to do, and a detailed 
exposition of this exercise has been done separately, Goodhart and Segoviano (2004), in a Financial Markets Group Discussion Paper. For an earlier exercise along these same lines, and using the same Mexican data set, see Segoviano and Lowe (2002). Amongst the problems are how to reconstruct a 'typical' bank portfolio; whether, and how, to deal with the problem of failing loans dropping out of the portfolio: and what account to take of the fact that Basel II is a regime change that may make banks alter their 'typical' behaviour. Very briefly, we reconstructed a typical bank portfolio as follows. We assumed that each portfolio consisted of 1000 loans, each one with equal exposure. From each specific country data sources, we obtained the through time proportion of assets (bonds for the U.S.A. or corporate loans for Mexico and Norwayl that were classified under each of the reported ratings for a given country. With this information we constructed the benchmark portfolio that we used to compute capital requirements at each point in time.

By assuming that the initial bank loan book remains unchanged throughout, this is equivalent to assuming that failed loans are replaced by loans of similar initial quality. This is what Kashyap and Stein (2004) did, and seems natural. Gordy and Howells (2004) argue, however, that banks will aim for a higher quality portfolio during recessions, and thus will replace failing loans with credits of higher, than initial, quality. At the macro level it is hard, in most countries, to see where the supply of such higher quality loans would come from during recessions; in discussion of this point at a BIS Conference in May 2004, Michael Gordy noted that in the U.S.A. high quality companies tended to shift their borrowing from capital markets, e.g. the commercial paper market, to banks during recessions. In any case, since risk spreads widen during recessions, any extra benefit would be slight. So we feel relatively comfortable about this assumption.

The results of this exercise for the three countries examined are stark. We compared the implied capital requirements for our 'typical' bank under three regulatory regimes; first the standardised approach in Basel II, (which is close to that applied in Basel I); second, the Foundations IRB approach, (i.e. assuming a constant Loss Given Default, since we have no good time series in any country for average LGD); and third, an Improved Credit Risk Method (ICRM). This latter uses a Merton approach to model credit quality changes and an indirect approach to model correlations amongst the individual credits in the overall portfolio. The construction of an ICRM is, however, 
quite complex, and interested readers should consult our companion paper, Goodhart and Segoviano (2004).

In a nutshell, this latter approach entalis deriving the distribution of the possible values that the portfolio of financial assets held by the bank can take. The potential different values that a portfolio could take - and their respective probabilities - are recorded in the so-called profit and loss distribution of the portfolio (P\&L). For risk management purposes, the Value at Risk measure (VaR), from which economic capital for a bank is defined, is obtained from this distribution. If a bank holds a portfolio of assets, we can then attempt to quantify how the diversification of its assets will affect the value of its portfolio. So, when computing the P\&L, the geographical location and industrial activity of the assets held in a portfolio are taken into account. When implementing this approach, we assumed that the benchmark portfolics had loans that were evenly distributed across geographical regions and industrial activities within their respective countries. We then programmed an algorithm that simulated 10,000 different 'quality scenarios' that might affect these portfoltos, and so produce a migration of loans between credit quality bands. Each quality scenario shows a change in the market value of the assets. and therefore the difference between the initial and final credit quality. Once the credit portfolio quality scenarios were simulated, we computed the losses/gains that come from the difference between initial and final credit qualities. The losses/gains obtained from the simulation process were used to build a histogram, which summarises the loss distribution of the credit portfolio. From this distribution a 'value at risk' (VaR) is defined from which we can obtain the amount of unexpected losses from the portfolio. The unexpected losses divided by the total amount of the portfolio represent the percentage that with, a given probability, (for example the 99.9 percentile) could be lost in an extreme event.

Anyhow, we have simulated the time paths of CARs under each of our three approaches, standardised. IRB Foundation (IRB F) and ICRM, for our various countries, and the results are set out in Tables 3 to 5 , and Figures 7 to 9 .

The important result to observe is the much greater variance of the simulated outcomes for the IRB than for the standardised or ICRM approaches. During periods of strong growth, high profits and low NPLs, (U.S.A. in the mid 1990s and Norway in 1997), the IRB has a 
TABle 3

CARS FOR THE U.S.A.

\begin{tabular}{cccc}
\hline \hline Period & Standardised & IRB F & ICRM \\
\hline 1982 & 9.597967 & 8.591044 & 8.070189 \\
1983 & 8.933900 & 7.185306 & 6.802057 \\
1984 & 8.933900 & 7.624870 & 7.032411 \\
1985 & 9.133900 & 8.024912 & 7.262765 \\
1986 & 9.463390 & 9.989917 & 8.736384 \\
1987 & 9.463930 & 9.824500 & 8.545390 \\
1988 & 9.463930 & 8.659141 & 6.990717 \\
1989 & 9.563390 & 10.804149 & 6.488127 \\
1990 & 9.563390 & 11.677029 & 7.601025 \\
1991 & 9.986339 & 11.434979 & 7.541649 \\
1992 & 9.687739 & 8.064210 & 6.470195 \\
1993 & 9.287739 & 6.468979 & 4.665018 \\
1994 & 8.901877 & 5.395182 & 3.783256 \\
1995 & 8.507394 & 5.561594 & 4.087216 \\
1996 & 8.246774 & $\mathbf{5 . 6 4 6 1 1 1}$ & 4.316443 \\
1997 & 8.294313 & 5.940010 & 4.837646 \\
1998 & 8.312774 & 6.508256 & 5.831926 \\
1999 & 8.403155 & 7.810893 & 6.704727 \\
2000 & 8.410316 & 8.126805 & $\mathbf{7 . 1 6 3 8 3 4}$ \\
2001 & 8.531238 & 8.245881 & 7.242604 \\
2002 & 8.312375 & 8.180511 & 6.779526 \\
2003 & 8.107739 & 6.603000 & 6.258685 \\
Average & $\mathbf{8 . 9 5 9 4 3 0}$ & $\mathbf{8 . 0 1 6 6 9 4}$ & $\mathbf{6 . 5 0 9 6 2 7}$ \\
Variance & $\mathbf{0 . 3 3 9 9 6 4}$ & $\mathbf{3 . 3 9 2 3 5 2}$ & $\mathbf{1 . 9 4 5 7 9 0}$ \\
\hline & & &
\end{tabular}

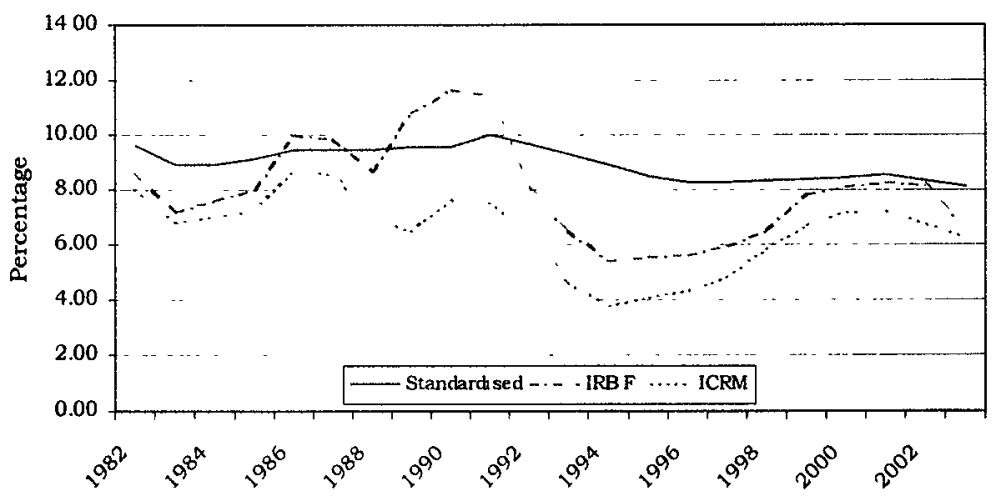

FIGURE 7

CARS FOR THE U.S.A. 
TABle 4

CARS FOR Norway

\begin{tabular}{crrr}
\hline Period & Standardised & IRB F & \multicolumn{1}{c}{ ICRM } \\
\hline 1989 & 9.991635 & 8.311481 & 7.580115 \\
1990 & 10.265155 & 9.275921 & 8.127573 \\
1991 & 10.465155 & 9.781705 & 8.675031 \\
1992 & 10.367155 & 9.929912 & 9.034373 \\
1993 & 10.265155 & 9.523779 & 9.186305 \\
1994 & 10.940239 & 13.235447 & 9.821542 \\
1995 & 11.320031 & 14.066170 & 11.082487 \\
1996 & 10.669155 & 12.141937 & 9.722593 \\
1997 & 10.265155 & 8.857323 & 7.317353 \\
1998 & 10.265155 & 9.001267 & 7.422621 \\
1999 & 10.265155 & 9.218641 & 7.527889 \\
2000 & 10.265430 & 9.486551 & 7.930505 \\
2001 & 10.360916 & 9.648655 & 8.333122 \\
2002 & 10.461360 & 9.764866 & 8.343509 \\
Average & 10.440489 & 10.160261 & $\mathbf{8 . 6 7 8 9 3 0}$ \\
Variance & $\mathbf{0 . 1 1 3 4 0 1}$ & $\mathbf{2 . 9 4 1 6 1 4}$ & $\mathbf{1 . 1 9 0 4 9 1}$ \\
\hline
\end{tabular}

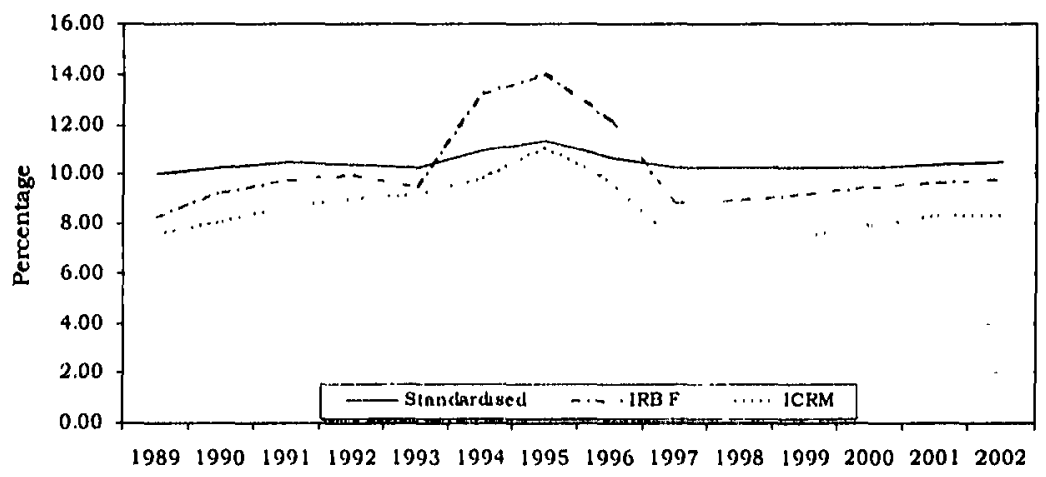

Figure 8

CARS FOR NORWAY 
TABLE 5

CARs FOR MEXICO

\begin{tabular}{crrr}
\hline Period & Standardised & IRB F & \multicolumn{1}{c}{ ICRM } \\
\hline Mar-95 & 8.765096 & 13.864230 & 10.462123 \\
Jun-95 & 9.221855 & 16.650790 & 12.285877 \\
Sep-95 & 9.299730 & 17.103009 & 12.714591 \\
Dec-95 & 9.493498 & 18.151470 & 12.820000 \\
Mar-96 & 9.251044 & 17.067542 & 12.589874 \\
Jun-96 & 9.494958 & 18.448561 & 13.248221 \\
Sep-96 & 9.557249 & 19.415843 & 14.891864 \\
Dec-96 & 10.303734 & 24.230942 & 17.645355 \\
Mar-97 & 9.430354 & 19.088714 & 15.153354 \\
Jun-97 & 9.273425 & 17.500911 & 13.895955 \\
Sep-97 & 9.396601 & 18.254201 & 14.344051 \\
Dec-97 & 8.928781 & 15.194116 & 14.796451 \\
Mar-98 & 8.813186 & 14.397932 & 13.673818 \\
Jun-98 & 8.851211 & 14.428160 & 12.256023 \\
Sep-98 & 9.058278 & 15.545394 & 11.622476 \\
Dec-98 & 9.040916 & 15.456234 & 11.797630 \\
Mar-99 & 9.052107 & 15.519282 & 12.003802 \\
Jun-99 & 8.981783 & 15.296608 & 12.251375 \\
Sep-99 & 9.135013 & 15.979265 & 12.725803 \\
Dec-99 & 8.968905 & 15.345409 & 12.100842 \\
Average & $\mathbf{9 . 2 1 5 8 8 6}$ & $\mathbf{1 6 . 8 4 6 9 3 1}$ & $\mathbf{1 3 . 1 6 3 9 7 4}$ \\
Variance & $\mathbf{0 . 1 2 2 6 6 2}$ & $\mathbf{5 . 6 4 4 9 6 5}$ & $\mathbf{2 . 5 8 8 2 0 5}$ \\
\hline
\end{tabular}

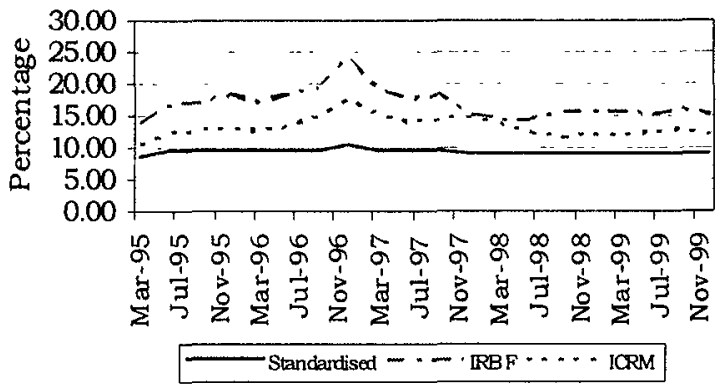

Figure 9

CARS FOR MEXICO 
TABLE 6

MaXimum \% Change in CARS

\begin{tabular}{|c|c|c|c|c|c|c|c|c|}
\hline \multirow[t]{2}{*}{ A. IRB } & \multicolumn{4}{|c|}{ Upwards } & \multicolumn{4}{|c|}{ Downwards } \\
\hline & $\begin{array}{c}1 \\
\text { Period }\end{array}$ & Date & $\begin{array}{c}2 \\
\text { Consecutive } \\
\text { Periods }\end{array}$ & Dates & $\begin{array}{c}1 \\
\text { Period }\end{array}$ & Date & $\begin{array}{c}2 \\
\text { Consecutlve } \\
\text { Perlods }\end{array}$ & Dales \\
\hline U.S.A. & 0.25 & 1989 & 0.333 & $1989 / 90$ & -0.29 & 1992 & .0 .49 & $1992 / 93$ \\
\hline Norway & 0.39 & 19394 & 0.45 & $1994 / 95$ & -0.27 & 19997 & -0.41 & $1996 / 97$ \\
\hline Mexico & 0.25 & $1)(0-9)$ & 0.330 & $\begin{array}{c}\text { Sep/s)er } \\
96\end{array}$ & -021 & Mar 97 & -0.30 & $\begin{array}{c}\text { Mar/Jun } \\
97 \\
\end{array}$ \\
\hline \multirow[t]{2}{*}{ B. ICRM } & \multicolumn{4}{|c|}{ Upwards } & \multicolumn{4}{|c|}{ Downwards } \\
\hline & $\begin{array}{c}1 \\
\text { Perlod }\end{array}$ & Date & $\begin{array}{c}2 \\
\text { Conseculive } \\
\text { Perlods }\end{array}$ & Dales & $\begin{array}{c}1 \\
\text { Period }\end{array}$ & Date & $\begin{array}{c}2 \\
\text { Conseculuve } \\
\text { Perlods }\end{array}$ & Dales \\
\hline U.S.A. & 0.21 & 1998 & 0.33 & $1998 / 99$ & -0.28 & 1993 & -0.47 & $1993 / 94$ \\
\hline Norway & 0.13 & 1995 & 0.20 & $1994 / 95$ & -0.25 & 1997 & -0.37 & $1996 / 98$ \\
\hline Mexjco & 0.18 & Dec-96 & 0.30 & $\begin{array}{c}\text { Sep/Dec } \\
96 \\
\end{array}$ & -0.14 & Mar-97 & -0.22 & $\begin{array}{c}\text { Mar/Jun } \\
97 \\
\end{array}$ \\
\hline \multirow[t]{2}{*}{$\begin{array}{c}C . \\
\text { Stand }\end{array}$} & \multicolumn{4}{|c|}{ Upwards } & \multicolumn{4}{|c|}{ Downwards } \\
\hline & $\stackrel{1}{\text { Period }}$ & Date & $\begin{array}{c}2 \\
\text { Conseculive } \\
\text { Periods }\end{array}$ & Dates & $\frac{1}{\text { Perlod }}$ & Date & $\begin{array}{c}2 \\
\text { Consecullve } \\
\text { Perlods }\end{array}$ & Dates \\
\hline U.S.A. & 0.04 & j111-05 & 0.06 & $1985 / 86$ & -0.07 & 1983 & -0.09 & $1994 / 95$ \\
\hline Norway & 0.07 & J1111-0.5 & 0.10 & $1994 / 95$ & -006 & 1997 & .010 & $1996 / 97$ \\
\hline Mexico & 0.08 & Dece-96 & 0.08 & $\begin{array}{c}\text { Sep/Dec } \\
\text { !) } 6\end{array}$ & -0.08 & $M a l^{*}-97$ & -0.10 & $\begin{array}{c}\text { Mar/Jun } \\
97\end{array}$ \\
\hline
\end{tabular}

lower CAR than the standardised approach in all our developed countries; whcreas in rccessions, (e.g. U.S.A. in 1990/91. Mexico mid $1995 / 96$ and Norway in 1994/95), the CAR is markedly higher for the IRB than in the other two approaches. In Mexico, an emerging market economy (EME), the average quality of loan is lower throughout than in developed countries, so the IRB gives a higher CAR in all years, but, as in developed countries, the variance of the CAR (up in recessions as in 1995/96, and lower during the better years) is greater for the IRB than in the other two approaches.

It follows that the \% change in the required CAR under the IRB as a country moves from boom to recession (up) and back to boom again (down) will be much more extreme under the IRB than under the other two approaches. This is shown in Table 6.

The implication of this is that procyclicality may well still be a serious problem with Basel II, cven after the smoothing of the risk 
curves that were introduced between Consultative Papers 2 and 3 produced by the Basel Committee to mitigate this problem. However there will be other potentially offsetting factors. Banks normally keep buffers above the required minimum CARs, both for their protection against sanctions should the minimum be infringed and to satisfy ratings agencies, and these buffers are likely to be raised during booms when IRB CARs may fall to extremely low levels. Note, however, that we have used Moody's data for the U.S.A. from 1982 to 2003, for Norway from 1988 to 2001 and for Mexico from 1995 to 2000 , which are already supposed to be averaged over the cycle, whereas most commercial banks are, so we are told by several of them, likely to use point-in-time ratings, which could worsen pro-cyclicality yet further.

\section{Conclusion}

Basel II will be a regime change, and one of the purposes of this is to make bankers more conscious of risk assessment and risk management. It has already succeeded in this. One hope is that it will induce bankers to be more prudent during booms despite declines in CARs. An implication of a move from the standardised to an IRB approach is that the individual bank making this transition will be encouraged to shift its portfolio to higher-quality, higher rated credits, because it then benefits from a lower CAR. This is good of itself, but the higher the quality the credit, the steeper is the risk curve, (relating quality to required risk ratio); so the procyclicality is likely to be enhanced, even if average quality improves.

When a regime change is introduced, no one in truth can predict its ramifications, certainly not us. Nevertheless these simulations suggest that procyclicality could remain a serious concern. It is even possible that, with the advent of a serious downturn, if one was to occur, the impact of abiding by the IRB would be too severe for the authorities in some countries to countenance. Perhaps like the Stability and Growth Pact it would only be observed in the breach when it began to bite hard. Possibly an even greater worry might be that the adoption of Basel II, while not being so adverse as to force reconsideration, might yet exacerbate future capital fluctuations.

Certainly there remains a tension between relating CARs more closely to underlying risks in individual banks, and in trying for 
macro-economic purposes to encourage contra-cyclical variations in bank lending in aggregate. How to square this circle must, however, be a subject for future research.

(Recetved 4 May 2005: Revised 28 October 2005)

\section{References}

Ablad, A., and Mody. A. Financial Reform: What Shapes It? What Shakes It? IMF Working Paper No. 03/70, 2003.

Acharya, V. V., Bharath, S. T., and Srinivasan, A. Understanding the Recovery Rates on Defaulted Securities. Paper in Progress, London Business School, 23 November Draft, 2003.

Altman, E. Altman Report on Defaulted Bonds and Bank Loans. Salomon Smith Barney. United States Corporate Bond Research High Yield, 2002.

Altman, E., Brady, B., Resti, A., and Sironi, A. The Link between Default and Recovery Rates: Implications for Credit Risk Models and Procyclicality. Working Paper, New York University, 2002.

Bank of England. Competition and Credit Control. London: Bank of England, May, 1971.

Basel Committee on Banking Supervision. International Convergence of Capital Measurement and Capital Standards. Basel, July 1988.

Capital Requirements and Bank Behaviour: The Impact of the Basel Accord. Basel Committee on Banking Supervision Working Paper No. 1. 1999.

Berger, A. and Udell, G. "Did Risk-Based Capital Allocate Bank Credit and Cause a Credit Crunch in the United States?" Journal of Money. Credit and Banking 26 (No. 3 1994): 585-628.

Bernanke, B., and Gertler, M. "Agency Costs, Collateral and Business Fluctuations." American Economic Revlew 79 (No. 1 1989): 14-31.

- "Monetary Policy and Asset Price Volatility." In New Challenges for Monetary Pollcy. Federal Reserve Bank of Kansas City, Economic Record 84 (No. 4 1999): 17-52.

Bernanke, B.. Gertler, M., and Gilchrist, S. "The Financial 
Accelerator in a Quantitative Business Cycle Framework." In J. B. Taylor and M. Woodford (eds.), Handbook of Macroeconomics 1C (1999): 1341-93.

Bordo, M., Eichengreen, B., Klingebiel, D., and Martinez-Peria, M. S. "Is the Crisis Problem Growing More Severe?" Economic Policy 16 (No. 32 2001): 51-82.

Brennan, M. J. "How Did It Happen?" Economic Notes 33 (No. 1 2004): 3-22.

Cecchetti, S., Genberg, H., Lipsky, J., and Wadhwani. S. Asset Prices and Central Bank Policy. Geneva Reports on the World Economy 2, 2000.

Clarida, R., Gali, J.. and Gertler, M. "The Science of Monetary Policy: A New Keynesian Perspective." Journal of Economic Literature 37 (No. 4 1999): 1661-707.

Collyns, C., and Senhadji, A. Lending Booms, Real Estate Bubbles and the Asian Crisis. IMF Working Paper 02/20, 2002.

Demirgüc-Kunt, A.. and Detriagiache, E. Financial Liberalisation and Financial Fragility. IMF Working Paper No. 98/83, 1998.

Dickey, D., and Fuller. W. "Likelihood Ratio Statistics for Autoregressive Time Series with a Unit Root." Econometrica 49 (No. 4 1981): 1057-72.

Drees, B., and Pazarbasioglu, C. The Nordic Banking Crises. Pitfalls in Financial liberalisation? IMF Occasional Paper No. 161, 1998.

Eichengreen, B., and Bordo, M. "Crises Now and Then: What Lessons from the Last Era of Financial Globalisation." In P. Mizen (ed.), Monetary History, Exchange Rates, and Financial Markets. Essays in honour of Charles Goodhart. Chapter 3, Vol. 2, Cheltenham, U.K.: Edward Elgar, pp. 52-91, 2003.

Elsinger, H., Lehar, A., and Summer, M. Risk Assessment of Banking Systems. Mimeograph, Oesterreichische Nationalbank, August, 2002.

Furfine, C. "Interbank Exposures: Quantifying the Risk of Contagion." Journal of Money, Credit and Banking 35 (No. 1 2003): 111-28.

Furfine, C. Interbank Exposures: Quantifying the Risk of Contagion. BIS Paper No. 70, June, 1999.

Gertler, M., Goodfriend, M., Issing, O., and Spaventa, L. Asset Prices and Monetary Policy: Four Views. Centre for Economic Policy Research (CEPR) and Bank for International Settle- 
ments (BIS), booklet, London: CEPR, 1998.

Glick, R., and Hutchison. M. "Banking and Currency Crises: How Common are the Twins?" Federal Reserve Bank of San Francisco Pacific Basin Working Paper No. PB 99-07, 1999.

Goodhart. C. A. E. "The Bank of England, 1970-2000," In R. Michie (ed.). The British Government and the City of London in the Twentieth Century. Chapter 17. Cambridge: Cambridge University Press. pp. 340-71. 2004.

Goodhart, C. A. E., and Segoviano, M. Basel and Procyclicality: A Comparison of the Standardised and IRB Approaches to an Improved Credit Risk Method. Financial Markets Group Discussion Paper 524. London School of Economics. October 2004.

Goodhart. C. A. E. Sunirand. P., and Tsomocos, D. P. A Model to Analyse Financial Fragility. Oxford Financial Research Centre Working Paper No. 2003fe 13, 2003.

Gordy. M. B.. and Howells. B. Procyclicality in Basel II: Can We Treat the Disease without Killing the Patient? Paper in Progress. Board of Governors of the Federal Reserve System, May 12 Draft. 2004.

Kaminsky, G., and Reinhart. C. "The Twin Crisis: The Causes of Banking and Balance-of-Payments Problems." American Economic Review 89 (No. 3 1999): 473-500.

Kaminsky, G., and Schmukler. S. Short-run Pain, Long-run Gain: The Effects of Financial Liberalization. NBER Working Paper 9787, 2003.

Kashyap, A. K., and Stcin, J. C. Cyclical Implications of the Basel-II Capital Standards. University of Chicago Working Paper, 2003, Available at http://gsbwww.uchicago.edu/fac/ anil.kashyap/research/basel-final.pdf. "Cyclical Implications of the Basel-II Capital Standard." Federal Reserve Bank of Chicago Economic Perspectives First Quarter (No. 1 2004): 18-31.

Kiyotaki, N., and Moore, J. "Credit Cycles." Journal of Political Economy 105 (No. 2 1997): $211-48$.

Leahy, M., Schich, S., Wehinger, G.. Pelgrin, F., and Thorgeirsson, $T$. Contributions of Financial Systems to Growth in OECD Countries. OECD Economics Department Working Paper No. 280, 2001.

Levine, R. "Financial Development and Economic Growth: Views 
and Agendas." Journal of Economic Literature 35 (No. 2 1997): 688-726.

MacKinnon. J. "Critical Values for Cointegration Test." In R. Engle and C. Granger (eds.), Long-Run Economic Relationships: Readings in Cointegration. Oxford: Oxford University Press, 1991.

Perron. P. "The Great Crash, the Oil Price Shock, and the Unit Root Hypothesis." Econometrica 57 (No. 6 1989): 1361-401.

- "Testing for a Unit Root in a Time Series Regression with a Changing Mean." Journal of Business and Economic Statistics 8 (No. 2 1990): 153-62.

- "Further Evidence from Breaking Trend Functions in Macroeconomic Variables." Journal of Economics 80 (No. 2 1997): 355-85.

Reid, M. The Secondary Banking Crisis, 1973-75: Its Causes and Course. London: Macmillan. 1982.

Reinhart, C.. and Tokatlidis, I. Before and after Financial liberalisation. University of Maryland, Mimeograph, 2001.

Segoviano, M., and Lowe. P. Internal Ratings, the Business Cycle and Capital Requirements: Some Evidence from an Emerging Market Economy. BIS Working Paper. September, Available at http://www.bis.org/publ/work1 17.pdf, 2002.

Secretariat of the Basel Committee on Banking Supervision. The New Basel Capital Accord: An Explanatory Note. Basel: BIS, 2001.

Upper, C., and Worms, A. "Estimating Bilateral Exposures in the German Interbank Market: Is There a Danger of Contagion?" European Economic Review 48 (No. 4 2004): 827-49.

Walsh, C., and Wilcox. J. Bank Credit and Economic Activity. In J. Peek and E. Rosengreen (eds.), Is Bank Lending Important for the Transmission of Monetary Policy? Federal Reserve Bank of Boston Conference Series No. 39, 1995.

Wells, S. "UK Interbank Exposures: Systemic Risk Implications." Bank of England, Financial Stability Review (December 2002): 175-82. 